NBER WORKING PAPER SERIES

\title{
MONEY-BASED VERSUS EXCHANGE \\ RATE-BASED STABILIZATION WITH \\ ENDOGENOUS FISCAL POLICY
}

\author{
Aaron Tornell \\ Andrés Velasco
}

\author{
Working Paper 5300
NATIONAL BUREAU OF ECONOMIC RESEARCH 1050 Massachusetts Avenue
Cambridge, MA 02138
October 1995

Earlier versions of this paper were presented at Dartmouth, MIT, Yale, the International Monetary Fund and the Inter-American Development Bank. We are grateful to seminar participants and to A. Alesina, R. Barro, R. Dornbusch, M. Gavin, R. Hausmann, E. Helpman, L. Leiderman, R. Perotti, J. Sachs, and M. Tommasi for comments and/or discussions. All errors are our own. Early work on this paper was done while both authors visited the Research Department of the Inter-American Development Bank, whose hospitality is gratefully acknowledged. Velasco's work was also supported by the Harvard/MIT RTG in Positive Political Economy while he visited Harvard in 1994-95. This paper is part of NBER's research program in International Finance and Macroeconomics. Any opinions expressed are those of the authors and not those of the National Bureau of Economic Research.

(C) 1995 by Aaron Tornell and Andres Velasco. All rights reserved. Short sections of text, not to exceed two paragraphs, may be quoted without explicit permission provided that full credit, including (c) notice, is given to the source. 


\title{
MONEY-BASED VERSUS EXCHANGE \\ RATE-BASED STABILIZATION WITH \\ ENDOGENOUS FISCAL POLICY
}

\begin{abstract}
We present a standard intertemporal model in which fiscal policy is determined by an optimizing but non-benevolent fiscal authority. If the fiscal authority is impatient, a money-based stabilization provides more fiscal discipline and higher welfare for the representative agent than does an exchange rate-based stabilization. Data for Latin American stabilizations in the last quarter-century seem to confirm the notion that stabilizing by using money rather than the exchange rate helps induce politicians to reduce the fiscal deficit.

Aaron Tornell

Department of Economics

Littauer M-6

Harvard University

Cambridge, MA 02138

and NBER

Andrés Velasco

Department of Economics

New York University

269 Mercer Street

New York, NY 10003

and NBER
\end{abstract}




\section{Introduction}

A key issue in the design of stabilization programs is the choice of a nominal anchor, which is a choice between money-based and exchange rate-based stabilization. Evaluations typically focus on the very short-run issue of bringing down inflation quickly with minimum real costs- hence the common emphasis on price stickiness and real exchange rate behavior. ${ }^{1}$

But bringing down inflation is only part of the story: keeping it down is the more difficult part. While most economists would agree that sustaining low inflation requires reducing the fiscal deficit and the associated demand for seigniorage, there has been little analysis of the link between the choice of nominal anchor and incentives to undertake fiscal reform. This paper attempts to fill that gap.

As Calvo (1987) and Helpman and Drazen (1987) have stressed, stabilization typically involves two different decisions: (i) technocrats at the Central Bank decide to pursue a tighter monetary policy, using either the money supply or the nominal exchange rate as an instrument; (ii) politicians who control the budget decide whether or not to tighten fiscal policy to make it compatible with the price stability aims of the Central Bank. The question we ask is this: Does the choice of monetary instrument by the Central Bank affect fiscal authorities' budget decisions? Informal policy advice often claims that it does, and that fixed rates are better because they put politicians in a disciplinary straightjacket ${ }^{2}$. Contrary to this conventional wisdom, we argue that by choosing a money-based stabilization Central Bank technocrats provide stronger incentives for fiscal authorities to close the deficit.

This is exactly what the experience of stabilization in Latin America over the last two decades shows: among countries that started with large fiscal deficits, a large majority of exchange rate-based stabilization plans implemented failed to accomplish fiscal reform and had to be abandoned, thus allowing inflation to resume; by contrast, in such countries the majority of money-based stabilizations induced fiscal adjustment and sustained price stability.

The theoretical insight is very simple. Under exchange rate-based stabilization, inflation falls sharply at first, but ongoing money-financed deficits eventually lead to the collapse of the peg and the end of the stabilization program. The politicians who control the budget can therefore enjoy high spending and low inflation today

\footnotetext{
${ }^{1}$ See the excellent survey by Calvo and Vegh (1994).

${ }^{2}$ See, for instance, Aghevli et. al.
} 
at the cost of high inflation in the future. Under money-based stabilization, on the other hand, failure to close the deficit is translated into expectations of high monetization in the future: as Sargent and Wallace (1981) showed, this means inflation today and not just in the future. Hence, under a money-based plan the politician pays for high spending today by having to endure inflation both today and in the future. Which type of plan will induce greater fiscal discipline depends on how much politicians discount the future. We show that if politicians are impatient, a stabilization under flexible rates induces greater fiscal adjustment by forcing the costs to be paid up front.

We formalize this idea in a standard setup of optimizing agents with price flexibility, perfect foresight and perfect capital mobility. It is well known (Helpman, 1981) that in this benchmark model the choice between fixed and flexible exchange rates is immaterial for a given path of government spending and taxes. The contribution of our paper is to identify precise distortions that characterize real-world stabilization programs, and embed them in a model within which a consistent comparison of exchange rate regimes can be carried out along the lines suggested by Helpman (1981). We depart from the benchmark case by endogenizing fiscal policy, and by introducing two distortions: i) the fiscal authority (FA) has the proclivity to spend more than is socially desirable because it derives utility from public spending (political power, prestige, etc.); and ii) the FA discounts the future at a rate higher than society (as a result, for instance, of uncertainty about being in office in the future).

With taxes fixed by assumption, all government spending in excess of tax revenue becomes a deficit, which must be financed through seignorage, the inflation tax or borrowing. ${ }^{3}$ The costs of higher spending derive from the fact that private agents' utility is a function of consumption and real money balances, and individual welfare is assumed to have some weight in the FA's objective function. Since higher anticipated inflation reduces demand for real balances, it reduces private agents' welfare, and is therefore costly to the government.

In the spirit of the typical real-world stabilization experiences, we consider a Central Bank (CB) which is independent of the FA, and analyze two alternative stabilization schemes. In one the $C B$ temporarily fixes the rate of change of the nominal exchange rate, and monetary policy is endogenous. We label this scheme Temporary Exchange Rate-Based Stabilization (TEBS). In the other, the $\mathrm{CB}$ temporarily fixes the growth rate of nominal money and the exchange rate is

\footnotetext{
${ }^{3}$ Or drawing down international reserves, which is the same as borrowing.
} 
endogenous. This is the case of Temporary Money-Based Stabilization (TMBS). Confronted with each monetary regime, the FA chooses its preferred level of the primary fiscal deficit, understanding that there is an intertemporal fiscal budget constraint.

In both cases we focus on "temporary" policies, in the sense that the CB can only precommit its monetary or exchange rate policy for a finite length of time. We do this for two reasons, one empirical and one theoretical. The empirical reason is that most monetary policy regimes -and especially fixed exchange rate experiments- are of limited duration. ${ }^{4}$ As Calvo (1986a and b, 1991) stresses, most attempted pegs face credibility problems, and are commonly regarded as temporary by investors and the public. The theoretical reason for this is that in a deterministic model such as the one we consider below, if the $\mathrm{CB}$ can precommit to an exchange rate rule for the entire future, the present value of monetary revenues is fixed. This in turn fixes the present value of fiscal deficits, and leaves no room for the FA to make any interesting decisions.

With fully flexible prices and purchasing power parity, the rates of inflation and devaluation are the same regardless of the exchange rate regime. ${ }^{5}$ Therefore, under an exchange-rate based stabilization the rate of inflation is whatever the $\mathrm{CB}$ chooses it to be regardless of what the FA does with the level of spending. If there is a deficit (after including the revenue from money creation), the shortfall will be made up by borrowing. This in turn means that inflation will have to rise (relative to its initial level) in the future in order to service the additional debt. Thus, by not reducing spending today the FA pays no cost in the short run, while inflation is low, but simply incurs the cost of high inflation in the future. ${ }^{6}$

Consider next the case where the CB fixes the rate of nominal money growth. If the FA does not eliminate the fiscal deficit, private agents will anticipate higher inflation in the future, for the same monetarist arithmetic reasons stressed by

\footnotetext{
${ }^{4}$ Klein and Marion (1994) study a sample of 61 pegged exchange rate episodes in Latin America since the $1950 \mathrm{~s}$, and find that they have a mean duration of 32 months, a median of 10 and a standard deviation of 49 .

${ }^{5}$ If non-trade goods are present, so that CPI inflation and devaluation are no longer the same, all theoretical arguments in the paper still apply, but quantitative effects may be altered.

${ }^{6}$ Calvo (1987) writes: "These remarks show how tempting it may be for a politician especially one who knows that his tenure will be over in the not-too-distant future-- to resort to anti-inflationary policy of this sort since a) no tough decision has to be taken in the short run; b) the policy immediately appears to be successful, and c) if well calibrated, the "bomb" will explode in the hands of his successor."
} 
Sargent and Wallace (1981) and developed further by Liviatan (1984) and Drazen (1985). As a result, inflation will be higher than it would have been under predetermined rates. In this case, the cost of high spending is spread over time: there is high inflation tomorrow (though lower than under predetermined rates), but there is also inflation today.

Focus now on the option faced by a FA that understands the trade-offs outlined above. Will it have more incentives to set a lower level of spending under predetermined exchange rates or under flexible rates? Our first result is that if the FA's discount rate is equal to the interest rate, both stabilization schemes are equivalent. However, if the FA discounts the future heavily (i.e., if its discount rate is larger than the world real interest rate), spending and the deficit are lower under a money based stabilization. Conversely, if the FA has a relatively low discount rate, there is more fiscal discipline under an exchange rate based program.

The intuition for this result is as follows. One can think of the choice of a nominal anchor under temporary stabilization as a decision about allocating the burden of the inflation tax across time. Under fixed rates the bulk of the tax burden is pushed to the future, when the peg is abandoned. In contrast, with flexible rates the inflation tax burden is spread across time. Given the FA's dislike for inflation, if its discount factor is small relative to the interest rate on debt, it prefers to finance any deficit with debt and raise higher inflation tax revenues in the future. An exchange rate based stabilization comes closer to implementing this preferred intertemporal allocation than does a money based program. This implies that the marginal cost of spending is higher under flexible rates, and therefore equilibrium spending is lower. Conversely, when the FA's discuunt factor is low, stabilization under flexible rates implements the FA's preferred presentfuture inflation mix more closely. Therefore, spending is lower under exchange rate-based stabilization.

What are the implications of this for the welfare of the representative private agent? Our second result is that the stabilization scheme that provides more fiscal discipline also provides higher individual welfare. In the model we consider, government spending does not enter the individual's utility function. But since such spending must be financed (at the margin) with distortionary inflation taxes, individual welfare is indirectly a decreasing function of the level of government spending, and statements about spending are easily translated into statements about welfare. In particular, if the FA's discount rate is relatively high, so that 
spending is lower under floating than under fixing, individual welfare is higher under floating. The opposite is true when the FA's discount rate is relatively low.

In the empirical section we consider the thirteen most widely-studied Latin American stabilization episodes of the last twenty-five years. The data reveals two striking facts: only one of the exchange rate-based programs (Argentina 1991) that began without having previously reduced the fiscal deficit managed to do so in the next three years. By contrast, four out of the five money-based attempts that started out without a previous fiscal adjustment achieved one in the course of the program. The exception was Bolivia in 1985, a case that is hardly clear cut: fiscal gains did initially take place, but they were wiped out by a fifty percent reduction in the price of Bolivia's major export and major source of fiscal revenue (tin) during the second year of stabilization. In short, the recent experience of Latin America provides little or no evidence to support the notion that exchange rate-based stabilizations induce more fiscal discipline than do money-based stabilizations.

The plan of the paper is as follows. In Section 2 we present the model, and in Section 3 we solve for the endogenous fiscal deficit. The two types of stabilization programs are compared in Section 4. We review the Latin American experience of the 1970s and 1980s in Section 5, and suggest some conclusions in Section 6.

\section{The Model}

We consider a standard model of a small open economy with price flexibility and perfect capital mobility. The economy is populated by a private sector and a government. We begin with a description of the private sector.

\subsection{The Private Sector}

The representative private agent consumes the single tradable good, which serves as the numeraire. She receives an endowment flow $y$ of this good in each period. She can store her wealth in an internationally traded bond, whose real value is denoted by $f_{t}$, or in domestic money, whose nominal outstanding stock is denoted by $M_{t}$. We will adopt the convention that asset stocks are chosen at the end of each time period. Hence, $M_{t}$ is the stock nominal balances chosen at the end of period $t$ and carried over to period $t+1$. Assuming purchasing power parity and letting the foreign price level be constant and equal to one we have that the 
nominal exchange rate is equal to the domestic price level: $E_{t}=P_{t}$.

The world lasts two periods: 1 and $2 .^{7}$ The timing of transactions is as follows. The agent enters period 1 with a stock of real bonds $f_{0}$ and a stock of nominal money $M_{0}$. During period 1 the agent receives production income $y$, interest payments $r f_{0}$ and a lump-sum transfer from the government $g$. She then pays taxes $\tau y,(\tau \in(0,1))$, consumes an amount $c_{1}$, and chooses the holdings of real money $m_{1} \equiv \frac{M_{1}}{E_{1}}$ and of the bond $f_{1}$ that she would like to carry over into period 2 . During period 2 the private agent uses all her accumulated wealth (including the real value of outstanding money balances) again to pay taxes $\tau y$ and to consume an amount $c_{2}$. During this period she does not receive any government transfers. It follows that the representative agent's budget constraint for period 1 is

$$
(1+r) f_{0}+m_{0}+y(1-\tau)+g=c_{1}+\pi_{1} m_{0}+m_{1}+f_{1}
$$

and that for period 2 it is

$$
(1+r) f_{1}+m_{1}+y(1-\tau)=c_{2}+\pi_{2} m_{1}
$$

where $r$ is the exogenous world real rate of interest, and $\pi_{t}$ is the rate of inflation and nominal devaluation, defined as: ${ }^{8}$

$$
\pi_{t} \equiv \frac{E_{t}-E_{t-1}}{E_{t}}
$$

Consolidating (2.1) and (2.2), and defining the domestic nominal interest rate as $i_{t} \equiv r+\pi_{t}$, we have

$$
(1+r)\left(f_{0}+m_{0}\right)+y(1-\tau)\left(\frac{2+r}{1+r}\right)+g=c_{1}+i_{1} m_{0}+\frac{c_{2}+i_{2} m_{1}}{1+r}
$$

which has the usual interpretation that the present value of expenditures must be equal to the present value of income. The representative agent's objective function is

$$
v\left(c_{1}\right)+\left(\frac{\epsilon}{\epsilon-1}\right) m_{0}^{\frac{\epsilon-1}{\epsilon}}+\left[v\left(c_{2}\right)+\left(\frac{\epsilon}{\epsilon-1}\right) m_{1}^{\frac{\epsilon-1}{\epsilon}}\right]\left(\frac{1}{1+r}\right), \quad \epsilon \in(0,1)
$$

\footnotetext{
${ }^{7}$ We will refer to the time before the world starts as period 0 . Policy announcements will be made at this time.

${ }^{8}$ Notice that we have defined the rate of inflation as $\frac{E_{t}-E_{t-1}}{E_{t}}$, rather than the conventional $\frac{E_{t}-E_{t-1}}{E_{t-1}}$. Under our definition, the rate of inflation is bounded above by one, and can therefore be interpreted readily as a tax rate. See Obstfeld (1989) for an elaboration on this point.
} 
where $v\left(c_{t}\right)$ has the usual properties. Notice three things about this function. First, it contains $m_{0}$ and $m_{1}$ rather than $m_{1}$ and $m_{2}$ because $m_{t-1}$ is the level of real money balances prevalent during $t$. Second, the individual's discount rate is the same as the rate of interest. Third, we have assumed $\epsilon \in(0,1)$ to ensure that total monetary revenue is increasing in $i_{t}$, so that the economy is always on the sensible side of the inflation Laffer curve. The need for this assumption will become clear later on in the paper.

\subsection{The Government}

The government consists of a Fiscal Authority (FA) and a Central Bank (CB). Next we present the consolidated accounts of both authorities. The government enters period 1 with a stock of net external debt $b_{0}$ and with nominal monetary liabilities $M_{0}$. During period 1 it transfers an amount $g$ to the private agent and pays interest $r b_{0}$ on its net debt. It finances these expenditures with tax revenue $\tau y$ and monetary revenue $\frac{M_{1}-M_{0}}{E_{1}}=\left(m_{1}-m_{0}\right)-\pi_{1} m_{0}$, which includes both seigniorage and the inflation tax. Any resulting deficit is covered by issuing more net debt. At time 2 the government must repay its outstanding debt (both real and monetary), and its only sources of income are tax revenue $\tau y$ and the inflation tax. Since taxes are fixed, the exchange rate must adjust to insure that the inflation tax is sufficient to balance the government accounts. ${ }^{9}$ It follows that the government budget constraints at times 1 and 2 are

$$
\begin{gathered}
(1+r) b_{0}+m_{0}\left(1-\pi_{1}\right)+g=\tau y+b_{1}+m_{1} \\
(1+r) b_{1}+m_{1}\left(1-\pi_{2}\right)=\tau y
\end{gathered}
$$

Consolidating (2.6) and (2.7) and using again the definition of $i_{t}$ we can write

$$
(1+r)\left(b_{0}+m_{0}\right)+g=\tau y+i_{1} m_{0}+\frac{\tau y+i_{2} m_{1}}{1+r}
$$

We can now combine 2.4 and 2.8 to obtain the economy-wide resource constraint:

\footnotetext{
${ }^{9}$ Having government expenditures at time 2 as well would not alter the results as long as utility remained separable both within and across time.
} 


$$
(1+r)\left(f_{0}-b_{0}\right)+y+\frac{y}{1+r}=c_{1}+\frac{c_{2}}{1+r}
$$

Given that the government consumes nothing, the present value of consumption simply equals the present value of national income, including income from initial net foreign assets.

\subsection{Solution to the Private Sector's Problem}

Next we solve the private sector's problem. Acting atomistically, the representative agent takes as given the announcement of $g$, and chooses $c_{1}, c_{2}, m_{0}$ and $m_{1}$ in order to maximize (2.5) , subject to (2.4). Letting an asterisk denote an equilibrium level, the first order conditions are

$$
\begin{gathered}
v^{\prime}\left(c_{1}^{*}\right)=v^{\prime}\left(c_{2}^{*}\right) \\
\left(m_{t-1}^{*}\right)^{-1 / \epsilon}=i_{t} v^{\prime}\left(c_{t}^{*}\right), \quad t=1,2
\end{gathered}
$$

Condition (2.10) indicates that consumption is constant across both periods: $c_{1}^{*}=c_{2}^{*}=\bar{c}$. Substituting this in (2.9) we have that

$$
\bar{c}=\left(\frac{1+r}{2+r}\right)\left[(1+r)\left(f_{0}-b_{0}\right)+y+\frac{y}{1+r}\right]
$$

which shows that consumption equals permanent income.

Condition (2.11) shows that money demand depends on the nominal rate of interest and the level of consumption. If we normalize the level of $\bar{c}$ in (2.12) so that $v^{\prime}(\bar{c})=1$, expression (2.11) can be written as

$$
m_{t-1}^{*}=i_{t}^{-\epsilon}, \quad t=1,2
$$

which is the money demand function we will use repeatedly throughout the paper. Notice from budget constraint (2.8) that total monetary revenue in each period equals $i_{t} m_{t-1}=i_{t}^{1-\epsilon}, t=1,2{ }^{10}$.

\footnotetext{
${ }^{10}$ Notice that total monetary revenues include both inflation tax and seigniorage. This is why the expression is $i_{t} m_{t-1}$ rather than $\pi_{t} m_{t-1}$. See Obstfeld (1989) for a more detailed treatment of this issue.
} 


\subsection{Stabilization Schemes}

As mentioned before, the FA and the $\mathrm{CB}$ make decisions independently of one another. In our setup, a stabilization is an act undertaken by the CB, independently of the FA. It is a temporary contraction, relative to what agents had been expecting, either of the devaluation rate or of the nominal money growth rate.

In a Temporary Money-Based Stabilization (TMBS) the CB sets period 1's growth rate of nominal money $\mu_{1} \equiv \frac{M_{1}-M_{0}}{M_{1}}$ equal to some constant, and the exchange rate becomes endogenous. In a Temporary Exchange Rate-Based Stabilization (TEBS) the CB sets period's 1 's nominal devaluation rate $\pi_{1}$ equal to some constant, and the money supply becomes endogenous ${ }^{11}$. In both cases, and as in Sargent and Wallace (1981), inflation in period 2 must adjust to ensure the government's budget constraint is met ${ }^{12}$.

The timing of actions is as follows. At the end of period 0 , the $\mathrm{CB}$ announces its monetary policy $\left(\mu_{1}\right.$ or $\left.\pi_{1}\right)$. Once monetary policy is announced, the FA announces $g$, the level of fiscal transfers that will take place at time 1 . Given these announcements, the private agent chooses $m_{0}$, her desired time 1 real balances. Lastly, the CB transfers to the private agent the gains (or losses) it made as a result of movements in the exchange rate during period 0 . During period 1 the private agent selects $c_{1}$ and $m_{1}$, her desired real balances for time 2 . The FA does not make any decision. ${ }^{13}$ When time 2 arrives the government repays its outstanding debt, the $\mathrm{CB}$ redeems the real value of outstanding money balances,

\footnotetext{
${ }^{11}$ Notice that if the CB were able to set the rate of devaluation for periods 1 and $2\left(\pi_{1}\right.$ and $\pi_{2}$ ) exogenously, then (by (2.13) the CB would fully determine $m_{0}$ and $m_{1}$. In that case, budget constraint (2.8) would leave the FA with no degrees of freedom: $g$ can only be the residual of total exogenous tax revenue (monetary and non-monetary) minus debt service:

$$
g=\tau y+i_{1}^{1-\epsilon}+\frac{\tau y+i_{2}^{1-\epsilon}}{1+r}-(1+r) d_{0}
$$

In this case the FA does not make any interesting decision.

${ }^{12}$ It makes no difference what the exchange rate regime is after stabilization is over. We simply assume that regimes are maintained into the second period. The common feature under both regimes is that the second-period devaluation rate is such that the inflation tax provides enough revenue to repay all government liabilities.

${ }^{13}$ We have required that government decisions be taken as having been made prior to the private agent's decisons in order to avoid time inconsistency problems. We have also assumed away price bubbles and other kinds of monetary indeterminacy which may be present under flexible rates.
} 
and the private agent consumes all her wealth.

\section{Endogenous Determination of Fiscal Policy}

The FA's optimization problem under the alternative stabilization schemes is the focus of this section. The FA has control over period 1's government transfers $g$, which it sets in order to maximize the following objective function

$$
\alpha u(g)+(1-\alpha)\left[v\left(c_{1}\right)+\frac{\epsilon}{\epsilon-1} m_{0}^{\frac{c-1}{\epsilon}}+\beta\left\{v\left(c_{2}\right)+\frac{\epsilon}{\epsilon-1} m_{1}^{\frac{\epsilon-1}{\epsilon}}\right\}\right]
$$

where $u(g)$ and $v(c)$ have the usual properties, $\beta$ is the FA's subjective discount factor, $\beta \in(0,1)$, and $\alpha \in(0,1)$. The key feature of this function is that government transfers $g$ yield utility -political power, prestige, greater chances of reelection, etc.- to those who control fiscal policy, and this element carries weight $\alpha$ in the FA's objective function. This is the first "political" distortion that leads the FA to set $g$ at a positive level in equilibrium -even though since all transfers are to be financed through distortionary taxation, the public's preferred level of $g$ would not be positive. At the same time, the FA also internalizes the objectives of the representative individual, but discounts the future at a rate $\beta$ that need not coincide with the individual's rate $(1+r)^{-1}$.

In setting $g$ the FA must trade off benefits against costs. The benefits of increasing $g$ derive from the increased utility of transfers. The costs derive from the fact that higher $g$ has to be financed with a higher inflation tax, which reduces equilibrium real balances in at least one, and maybe both, periods. To determine which stabilization provides more fiscal discipline we need to find the effects of changes in $g$ on inflation rates, and thus on $m_{0}$ and $m_{1}$.

Notice that, in maximizing 3.1 with respect to $g$, the FA obtains the following first order condition:

$$
\alpha u^{\prime}(g)=-(1-\alpha)\left[m_{0}^{-1 / \epsilon}\left(\frac{d m_{0}}{d g}\right)+\beta m_{1}^{-1 / \epsilon}\left(\frac{d m_{1}}{d g}\right)\right]
$$

Of course, the effect of changes in $g$ on money holdings and inflation in each period is different under each of the two stabilization schemes. Under TEBS $\pi_{1}$ is predetermined by the CB. Thus $m_{0}$ remains unchanged, and any change in $g$ just affects $m_{1}$. Under TMBS, on the other hand, the CB only fixes $\mu_{1}$, while inflation rates -and thus $m_{0}$ and $m_{1}-$ are endogenous and dependent on the choice of $g$. 
Before we proceed we must impose an upper bound on initial government debt to ensure government solvency. Notice that since the upper bound for the inflation rate is $\pi=1$, the money demand function (2.13) implies that the maximum attainable monetary revenue is $(1+r)^{1-\epsilon}$ per period. Substituting this upper bound in (2.8) it follows that initial government debt must satisfy the following inequality

$$
(1+r)\left[b_{0}+(1+r)^{-\epsilon}\right]+\bar{g} \leq \frac{2+r}{(1+r)^{\epsilon}}+\frac{\tau y}{1+r}
$$

where $\bar{g}=\max \left[g_{T E B S}^{*}, g_{T M B S}^{*}\right]$.

\subsection{Fiscal Policy under Exchange Rate-Based Stabilization}

Once the $\mathrm{CB}$ announces $\pi_{1}$ and the FA announces $g$ at the end of period 0 , private agents rearrange their portfolios by buying or selling domestic money from the $\mathrm{CB}$. The nominal exchange rate $E_{0}$ is given by history and cannot jump under TEBS. Let $\frac{M_{0^{-}}}{E_{0^{-}}} \equiv m_{0^{-}}$and $b_{0^{-}}$be the levels of real balances and net foreign assets outstanding before the policy announcements are made. Portfolio rebalancing is accomplished through the following asset swap: $\frac{M_{0}-M_{0-}}{E_{0}} \equiv m_{0}-$ $m_{0^{-}}=-\left(b_{0}-b_{0^{-}}\right)$. Substituting this into budget constraint (2.8) and using (2.13) to eliminate the $i_{t}$ 's, we have

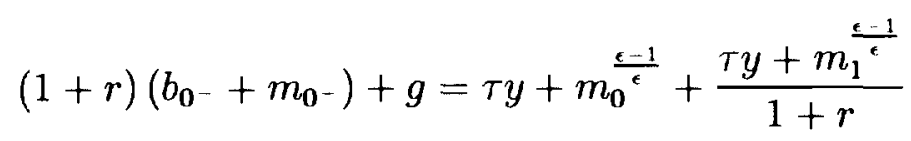

An equilibrium under TEBS is a quadruple $\left(g^{*}, m_{0}^{*}, m_{1}^{*}, \pi_{2}^{*}\right)$ that satisfies the FA's first order condition 3.2, the government's budget constraint (3.4), the money demand equation (2.13) and the devaluation rate $\pi_{1}$ set by the CB.

In order to obtain the equilibrium level of $g$ note that under TEBS, given that $\pi_{1}$ and therefore $m_{0}$ are exogenous, $\frac{d m_{0}}{d g}=0$. To obtain $\frac{d m_{1}}{d g}$ we differentiate budget constraint (3.4) and obtain

$$
\frac{d m_{1}}{d g}=-m_{1}^{1 / \epsilon}(1+r)\left(\frac{\epsilon}{1-\epsilon}\right)
$$

Combining (3.2) and (3.5) we have

$$
u^{\prime}\left(g_{T E B S}^{*}\right)=\left(\frac{1-\alpha}{\alpha}\right)\left(\frac{\epsilon}{1-\epsilon}\right) \beta(1+r)
$$


Since $u^{\prime \prime}(g)<0,(3.6)$ uniquely determines the level of $g_{T E B S}^{*}$. Substituting this value of $g$ and the value of $m_{0}\left(\pi_{1}\right)$ implied by (2.13), into budget constraint (3.4), yields a unique level of $m_{1}$. Lastly, the money demand (2.13) uniquely determines $\pi_{2}$. This completes the characterization of equilibrium under TEBS.

Note that $g_{T E B S}^{*}$ is not a function of $\pi_{1}$. This is because in the case of C.E.S. utility the difference between a) the marginal cost of lower money balances $m_{1}$ and b) the marginal benefit of higher inflationary revenue, is independent of the actual level of $m_{1}{ }^{14}$.

\subsection{Fiscal Policy under Money-Based Stabilization}

Under TMBS, at the end of period 0 the CB announces $\mu_{1}$ and the FA announces $g$. Once again, and using their expectations of $\pi_{1}$ that correspond to these announcements, agents attempt to rearrange their portfolios. The situation is slightly more complex than under TEBS, for under TMBS the CB does not intervene in the foreign exchange market, so the market can only clear as a result of an exchange rate movement at time zero. Let $m_{0}^{*}$ be the stock of real balances agents want to hold given the announcements. It must be the case that $m_{0}^{*}=\left(1-\pi_{0}\right) m_{0^{-}}$, with $\pi_{0} \equiv \frac{E_{0}-E_{0-}}{E_{0}}$. Hence, in this case private agents experience a capital loss (gain) of magnitude $\pi_{0} m_{0^{-}}$that has a counterpart in an equal gain (loss) for the government. There was no such effect on the government budget constraint was absent in the TEBS case. In order to carry out a consistent comparison of stabilization schemes under alternative nominal anchors it is necessary to offset this additional revenue-raising capacity of the government under TMBS. We assume that at the end of period 0 the government gives a rebate to agents equal to

$$
s_{0}=\pi_{0} m_{0}
$$

Private agents, of course, acting atomistically, do not internalize the effect their demand for real balances has on the size of the rebate. Since $m_{0}^{*}$ is all the real domestic balances they wish to hold, agents use the government transfer to buy bonds. Thus, the stock of interest-yielding assets they carry into period 1 is $b_{0}=b_{0^{-}}+s_{0}$. By substituting this and (3.7) into budget constraint (2.8) it follows that the government budget constraint is given by (3.4). Hence, under TMBS the FA faces the same intertemporal budget constraint as under TEBS.

\footnotetext{
${ }^{14}$ Mechanically, both the marginal utility cost and the marginal revenue benefit are of the form $m_{1}^{-1 / \epsilon}$.
} 
An equilibrium is a quintuple $\left(g^{*}, m_{0}^{*}, m_{1}^{*}, \pi_{1}^{*}, \pi_{2}^{*}\right)$ that satisfies the FA's first order condition (3.2), the government budget constraint (3.4), and two money demand equations, one of which is 2.13 . Since $\pi_{1}$ is now an endogenous variable, we need another equation to determine the system. From the definition of real balances we get the identity

$$
m_{1}\left(1-\mu_{1}\right) \equiv m_{0}\left(1-\pi_{1}\right)
$$

where $\mu_{1}$ is exogenously set by the CB. Using (2.13) and (3.8) we obtain

$$
\frac{d m_{0}}{d m_{1}}=\frac{1-\mu_{1}}{(1+r)+\left(\frac{1-\epsilon}{\epsilon}\right) i_{1}}
$$

Differentiating (3.4) totally we have that

$$
\frac{d m_{1}}{d g}=-\left(\frac{\epsilon}{1-\epsilon}\right)\left[m_{0}^{-1 / \epsilon}\left(\frac{d m_{0}}{d m_{1}}\right)+\frac{m_{1}^{1 / \epsilon}}{1+r}\right]^{-1}
$$

Finally, combining (2.13), (3.2), (3.9) and (3.10) we have

$$
u^{\prime}\left(g_{T M B S}^{*}\right)=\left(\frac{1-\alpha}{\alpha}\right) \beta(1+r)\left(\frac{\epsilon}{1-\epsilon}\right)\left[\frac{1+x}{1+x \beta(1+r)}\right]
$$

where

$$
x \equiv\left(\frac{1}{\beta}\right)\left(\frac{i_{1}^{*}}{i_{2}^{*}}\right)\left[\frac{\left(1-\mu_{1}\right)}{(1+r)+\left(\frac{1-\epsilon}{\epsilon}\right) i_{1}^{*}}\right]
$$

The equilibrium $\left(g_{T M B S}^{*}, m_{0}^{*}, m_{1}^{*}, \pi_{1}^{*}, \pi_{2}^{*}\right)$ is the solution to the two money demand equations (2.13) and to (3.4), (3.8), and (3.11).

\section{Comparing Alternative Stabilization Schemes}

In this section we compare the fiscal discipline exerted by TEBS and TMBS, and the welfare levels attained by the representative agent under each program. 


\subsection{Fiscal Discipline}

We define fiscal discipline in terms of the level of fiscal transfers $g$ made by the FA. Of course, changes in transfers are reflected one-to-one in changes in the fiscal deficit. Thus, the stabilization scheme that induces more fiscal discipline is the one that induces a lower $g$.

A comparison of (3.11) and (3.6) provides an unambiguous ranking of the levels of fiscal discipline under both stabilization schemes. To see this, note that the R.H.S. of (3.11) is equal to the R.H.S. of (3.6) multiplied by the term in square brackets. The term in square brackets in (3.11) is equal to one if $\beta=(1+r)^{-1}$, greater than one when $\beta(1+r)<1$, and smaller than one when $\beta(1+r)>1$. Since $u^{\prime \prime}(g)<0$ by assumption, it follows that the ranking of $g_{T E B S}^{*}$ and $g_{T M B S}^{*}$ depends only on the value of $\beta(1+r)$. We state this result in the following proposition:

Proposition 4.1. The ranking of fiscal discipline induced by alternative stabilization schemes is only a function of the ratio of the fiscal authority's discount factor $\beta$ and the gross interest rate $1+r$ :

- Both schemes induce the same degree of fiscal discipline if $\beta=(1+r)^{-1}$

- Money-based programs induce more discipline if fiscal authorities are impatient: $\beta<(1+r)^{-1}$

- Exchange rate-based programs induce more discipline if fiscal authorities are patient: $\beta>(1+r)^{-1}$.

To clarify the intuition behind this proposition, one can think of the choice of a nominal anchor as a specific rule to distribute the burden of the inflation tax intertemporally. Consider the experiment of increasing the level of fiscal transfers. Under TEBS, the entire increase in the inflation tax necessary to finance the fiscal expansion is shifted to the future. Under TMBS, this necessary increase in inflationary finance is spread between the present and the future. This spreading occurs because under rational expectations and floating rates, higher money creation tomorrow means higher inflation today as well as tomorrow. If fiscal authorities strongly discount the future $(\beta(1+r)<1)$, TEBS implements an intertemporal distribution of the inflation tax burden which is closer to the FA's preferred one. This implies that the marginal cost of financing an increase 
in $g$ using money financing is lower under TEBS than under TMBS. As a result, $g_{T M B S}^{*}>g_{T E B S}^{*}$.

To sum up, the source of the discipline effect in our model is the intertemporal allocation of the inflation tax burden induced by the alternative stabilization schemes. The less attractive this intertemporal allocation is to the FA, the stronger the fiscal discipline under the scheme. In particular, when the FA discounts the future at a rate higher than the world rate of interest, TMBS provides more discipline.

Notice that, interestingly, Proposition 4.1 holds for any level of $\pi_{1}$ and $\mu_{1}$, regardless of how tight or ambitious the temporary stabilization program is. Moreover, the connection between the "tightness" of each program and the degree of fiscal discipline it induces is revealing. We see immediately from 3.6 that $g_{T E B S}^{*}$ does not depend on $\pi_{1}$, so that tightening up the temporary stabilization program by slowing down the rate of nominal devaluation does not affect fiscal discipline. By contrast, we show in Appendix 1 that $\frac{\partial g_{\text {TMBS }}^{*}}{\partial \mu}>0$. Mechanically, this comes simply from using money demand function 2.13 to express equations $3.4,3.8$ and 3.11 in terms of $g$ and $i_{1}$, with $\mu_{1}$ as an exogenous parameter. Total differentiation then yields the desired result.

The following proposition summarizes this result:

Proposition 4.2. A tighter TEBS does not affect the degree of fiscal discipline. A tighter TMBS increases fiscal discipline.

The result presented here is somewhat extreme, because $g_{T E B S}^{*}$ does not adjust at all. The general principle, however, should still hold in more general formulations: because a FA that discounts the future heavily would prefer to defer the inflationary costs until the second period, and because it can do so more readily under TEBS than under TMBS, the latter prompts the FA to carry out greater adjustment.

\subsection{Welfare Comparisons}

Next we address the issue of which stabilization scheme generates higher welfare for private agents. Using (3.4) to eliminate the term $\left[m_{0}^{\frac{\epsilon-1}{\epsilon}}+\left(\frac{1}{1+r}\right) m_{1}^{\frac{\epsilon-1}{e}}\right]$ from the private agent's payoff function, it follows that the indirect utility function of 
the representative agent is

$$
V^{P A}=v(\bar{c})+\frac{v(\bar{c})}{1+r}+\left(\frac{\epsilon}{\epsilon-1}\right)\left[(1+r)\left(b_{0^{-}}+m_{0^{-}}\right)+g-\left(\frac{2+r}{1+r}\right) \tau y\right]
$$

Since $\epsilon<1$ by assumption, and all variables other than $g$ in (4.1) are exogenous, it follows that $V^{P A}$ is decreasing in $g$. Thus, using the ranking of the $g^{\prime} s$ for different parameter values provided by Proposition 4.1, we can derive the following result:

Proposition 4.3. The welfare attained by private agents under alternative stabilization schemes is only a function of the ratio of the fiscal authority's discount factor $\beta$ and the gross interest rate $1+r$ :

- Both schemes induce the same welfare if $\beta=(1+r)^{-1}$

- Money-based programs generate more welfare if fiscal authorities are impatient: $\beta<(1+r)^{-1}$

- Exchange rate-based programs generate more welfare if fiscal authorities are patient: $\beta>(1+r)$

The intuition for this result is very simple. Given that the individual's discount rate is always the same as the world rate of interest, and given that the revenue from money creation in each period $m_{t}^{\frac{\epsilon-1}{\epsilon}}$ is of the same form as the instantaneous utility function, the private agent is indifferent about the intertemporal allocation of the inflation tax. She only cares about the present value of this tax. Since this present value is strictly increasing in the level of transfers, it follows that the higher the level of transfers in any given stabilization scheme, the lower the welfare of the private agent. In particular, when TMBS leads the FA to set a lower level of transfers than it would under TEBS, welfare is higher under TMBS.

Of course, the extreme simplicity of this result is due to the specification of preferences, but the thrust of the result would hold more generally. Under other types of preferences, the agent would care about the intertemporal allocation of the inflation tax as well as its present value. As long as the instantaneous utility function was concave, the regime that provided more fiscal discipline would also yield higher private welfare if the time path of real money balances that it induced were "smoother". But if we think that TMBS is likely to provide more fiscal discipline, this qualification should not create much of a problem. Since under 
TMBS the exchange rate can move in anticipation of future events, the time path of real balances will be smoother under TMBS than under TEBS for any degree of fiscal discipline. Therefore, if individual preferences are for smoothing the path of money holdings, this fact provides an additional channel through which TMBS can provide higher welfare than TEBS. ${ }^{15}$

The next result is a straightforward implication of Proposition 4.2 and the fact that welfare is a strictly decreasing function of the degree of fiscal discipline:

Proposition 4.4. A tighter TEBS does not affect individual welfare. By contrast, a tighter TMBS increases individual welfare.

Notice that these results stand in sharp opposition to Calvo's (1986a, 1991), who argued that the best temporary stabilization is no temporary stabilization at all. In our context that is not true for either exchange rate regime. Under fixing, a temporary stabilization has no effect on welfare, while under a floating exchange rate regime and in the realistic case of impatient policymakers, reducing money growth causes individual welfare to increase relative to the pre-stabilization level. The difference is that Calvo took fiscal policy as exogenous and focused on the welfare costs of intertemporal distortions in consumption and money-holdings, while our model focuses on the beneficial effects of fiscal discipline and skirts the issue of costly intertemporal distortions. Of course, the full truth lies in a model that incorporates both effects. However, we regard it as important to highlight a previously neglected channel through which temporary stabilizations can affect individual welfare.

\section{Latin American Stabilization and Fiscal Adjustment}

If the conventional wisdom were correct, we would find that in practice fiscal adjustment tends to follow the adoption of exchange rate-based stabilization programs. In this section we consider the thirteen most widely-studied stabilization experiments in the recent history of Latin America, and show that there is little if any evidence from this sample to confirm the conventional wisdom. ${ }^{16}$ By contrast,

\footnotetext{
${ }^{15}$ Calvo (1991) makes the same point in a slightly different context (one in which fiscal policy is exogenous), arguing that the welfare losses from "temporary stabilization" are likely to be lower under TEBS than under TMBS.

${ }^{16}$ See, for example, the wide-ranging and well known volumes edited by Bruno, di Tella, Dornbusch and Fischer (1988) and Bruno, Fischer, Helpman, Liviatan and Meridor (1991), and
} 
we find that countries undertaking money-based stabilizations are more likely to achieve fiscal consolidation in the course of their programs.

Inclusion in the sample is based on three criteria:

i) We consider only episodes that took place after 1970. While there are certainly many interesting stabilization experiences prior to that date, data limitations (particularly in the fiscal area) make analysis of them treacherous.

ii) All the attempted stabilizations in our sample involve countries with a history of fiscal difficulties, and in all of them seigniorage played an important role in the financing of budget deficits. This is in keeping with the spirit of our model, in which the main role of exchange rate policy is to affect inflation and seigniorage collection.

iii) We only include comprehensive and serious stabilization attempts. Temporary measures (such as wage-price controls unaccompanied by any aggregate demand restraint) adopted as mere stop-gaps cannot influence fiscal policy. For this reason, we have excluded the sequence of mini-plans implemented in Argentina after the collapse of the 1985 Plan Austral, and in Brazil after the collapse of the 1986 Plano Cruzado. ${ }^{17}$ We also leave out populist expansionary policies that appropriated the label of stabilization, as was the case in Chile under Allende (1970-73), in Argentina under Peron and Isabelita (1973-76), and in Nicaragua under the Sandinistas (1979-1990). The experience of Peru under Alan Garcia is included because his plan initially seemed broad and comprehensive and was viewed as such at the time, even though it eventually degenerated into a standard populist episode. ${ }^{18}$

All fiscal data, except those for Chile in 1974-78 and the Dominican Republic in 1989-92, are from the United Nations Economic Commission for Latin America

the influential papers by Helpman and Leiderman (1988), Kiguel and Liviatan (1988, 1992a and b), Vegh (1992) and Calvo and Vegh (1994).

${ }^{17}$ In the second half of the 1980s, and under the stewardship of the Radical Party, Argentina implemented the February Plan, the Primavera I and Primavera II Plans, and the Austral II Plan. After the advent of the Peronist Administration, the short-lived Bunge-Born and Bonex plans were put into effect. Brazil in the same period tried the Cruzado II, the Bresser Plan and the Summer Plan. As the very proliferation of plans and labels suggests, these were not comprehensive attempts at bringing down inflation. The experiences are discussed in papers by D. Heymann, E. Cardoso and M. Kiguel-N. Liviatan, all in the 1991 volume edited by Bruno et al.

${ }^{18}$ These experiences are discussed in papers by F. Sturzenegger, F. Larrain and P. Meller, R. Lago and J.A. Ocampo, all in the volume editied by Dornbusch and Fdwards (1991). 
and the Caribbean (ECLAC). ${ }^{19}$ This agency undertook a comprehensive project to compile and standardize Latin American fiscal data. Their results are summarized in ECLAC (1992). The definitions of government we use correspond to the NonFinancial Public Sector or to the Consolidated Government. Such definitions cover the central government, its decentralized agencies and state owned enterprises. Coverage of state or local government is minimal, though it varies somewhat from country to country. In every case, we exclude quasi-fiscal activities undertaken by the Central Bank.

In Table 1 we present the relevant fiscal data. We have provided 4 years of data for each stabilization episode: year $t$ is the year the stabilization was undertaken, and we provide data for years $t-1, t, t+1$ and $t+2$. Notice that if the stabilization plan was put into place during the last quarter of any given year, the following year is classified as year $t$. We present two summary indicators of the fiscal stance, both of them as percentages of nominal GDP. The first is the nominal fiscal balance ${ }^{20}$. The second is the primary fiscal balance, in which all net interest payments have been subtracted from the nominal deficit. In the appendix we present detailed accounts of the thirteen stabilization episodes.

Table 2 classifies these thirteen stabilization episodes according to two criteria. The first is whether the program was exchange rate-based or money-based. ${ }^{21}$ The other is whether fiscal tightening occurred before the period of monetary stabilization, during the period, or not at all. In the first case it is clear that factors other than the monetary stabilization induced the fiscal consolidation; in the second and third cases, one might argue that the choice of stabilization scheme did influence the incentives to carry out a fiscal consolidation. Clearly, the predictions of our model apply only to the last two cases. In Table 2 we use something akin to the Maastricht standard for classifying fiscal performance: consolidation occurs if the nominal fiscal deficit is below $3 \%$ of GDP for three out of four years. Consolidation is said to happen before monetary stabilization if the standard is

\footnotetext{
${ }^{19}$ ECLAC data does not cover the 1970s; the Dominican Republic is not included in their data base.

${ }^{20}$ For Mexico and Brazil, where the government has large domestic currency debt, we have followed the standard procedure of subtracting the inflationary component of interest pay ments, thus giving rise to the more useful concept of the operational deficit.

${ }^{21}$ Inevitably, not all cases lend themselves to such clear-cut classification. Some episodes listed as money-based stabilizations (Chile 1975, Bolivia 1985, Brazil 1990) did not display a clean exchange rate float, but rather a managed float or a policy of occasional mini-devaluations; still, money provided the main nominal anchor.
} 
met in year $t-1$ and maintained in two out of the following three years ${ }^{22}$; it is said to happen during monetary stabilization if the standard is not met in $t-1$ but is met in years $t, t+1$ and $t+2$; in all other cases, it is said not to have happened .

A caveat is in order. There are two reasons why the data overstates the degree of fiscal discipline induced by exchange rate-based stabilizations. First, it is clear that such stabilizations bring down inflation much more swiftly than do moneybased ones, as the exchange rate strongly anchors down the price of tradeables. In countries with non-indexed tax systems, the sharp fall in inflation causes a quick and quantitatively important increase in the real value of tax revenue. The same thing happens with regard to the recently adjusted real prices of services delivered by state enterprises (electricity, water, telephones, etc.). Hence, a fall in the deficit can occur even if no politically painful fiscal effort is made. Second, it is by now a widely-accepted fact that exchange rate-based stabilizations cause an initial boom and then a recession; by contrast, money-based stabilizations typically induce an initial recession followed by expansion. ${ }^{23}$ Hence, under TEBS the boom-led increase in tax revenues creates an illusion of fiscal adjustment that is absent under TMBS.

Despite this overstatement, Table 2 reveals a striking fact: only one of the exchange rate-based programs (Argentina 1991) that started out without previous fiscal consolidation managed to achieve it. Even this case is not clear-cut, for Argentina had already made important fiscal progress in the first two years of the Menem administration: the nominal deficit went from $6.0 \%$ of GDP in 1.988 (the year before the change in government) to $3.8 \%$ in 1989 and 1990.

The most often cited and extreme case of failure to clean up the fiscal house after having reduced inflation by means of an exchange rate anchor is that of Brazil's Cruzado Plan in 1986. The sharp fall in inflation weakened whatever political will the government may have had to tackle the costly task of budget-cutting. Ac-

\footnotetext{
${ }^{22}$ According to Aspe (1993), the Mexican Minister of Finance, “...an enormous fiscal adjustment effort was made with the understanding that it was a prerrequisite for succesful stabilization..." The earlier experience of other countries in the region, where quick success at bringing dow inflation via exchange-rate and price freezes had done away with the political urgency to reduce the deficit, loomed large: "...non-orthodox programs were implemented in Argentine, Brazil and Israel. However, President de la Madrid's administration avoided sucumbing to the temptation of rushing into this type of program. It was better to wait until public finances were healthy..."

${ }^{23}$ See, for instance, Calvo and Vegh (1994).
} 
cording to Modiano (1988) $)^{24}$, the situation of fiscal disequilibrium "...would only grow during the Cruzado Plan as a result of the increase in expenditures on the government wage bill, direct and indirect subsidies, tax-exemptions, and transfers to state enterprises and state and local authorities." Such behavior was not unrelated to the fact that elections for state governments and the constituent assembly would take place in November of that year.

A second striking fact in Table 2 is that four out of the five money-based attempts that began without a previous fiscal consolidation succeeded in achieving a consolidation in the course of their programs. This is precisely in line with the predictions of our model. The fifth case, that of Bolivia in 1985, is also somewhat ambiguous. Bolivia achieved some impressive initial fiscal gains, with the nominal deficit falling from 25.7 percent of GDP in 1984 to 10.3 percent in 1985 , and to 2.7 percent in 1987. Its failure to classify as having achieved fiscal adjustment is largely due to a massive shock in the terms of trade: between 1985 and 1986, the price of tin (the country's largest export and largest source of fiscal revenue) was almost halved, and remained at that depressed level for the next two years.

Of course, this evidence should be taken with a grain of salt. Many things happen during these episodes, and it is difficult to isolate the effects that the exchange rate regime has on fiscal policy. Nonetheless, the Latin American stabilization experiments of the last two decades do suggest that there is little evidence in support of the idea that exchange rate-based stabilization programs induce more fiscal discipline than money-based programs.

\section{Summary and Conclusions}

This paper offers both theoretical reasons and some empirical evidence to suggest that the conventional wisdom that exchange rate-based stabilizations provide more fiscal discipline than money-based stabilizations is in need of revision.

On theoretical grounds, we argue that under temporary stabilization the choice of nominal anchor is essentially a choice of when to collect the inflation tax necessary to cover the fiscal deficits. In turn, this choice determines the costs fiscal authorities must pay if they want to increase the deficit. If fiscal authorities are impatient, flexible rates provide more fiscal discipline; the opposite is true if fiscal authorities are relatively patient.

\footnotetext{
${ }^{24}$ In Bruno et, al (1988).
} 
Our claim is not that fiscal discipline can be achieved only under floating exchange rate regimes. Fiscal discipline depends on both economic fundamentals -preferences, government access to capital markets- and on political fundamentals -underlying institutions, budget-making rules and degree of distributive tensions. Our claim is simply that in situations where there is no fiscal discipline to begin with, fixed rates per se do not guarantee it; conversely, flexible rates may tilt the balance in favor of greater discipline because of the immediacy of the punishment associated with imprudent fiscal policies.

Some preliminary evidence suggests that the conventional wisdom is at variance with the facts, at least in some regions of the world. In Latin America in the last quarter-century, it is hard to find a country that undertook an exchange rate-based stabilization while still suffering from a fiscal problem and managed to correct this problem in the course of the program. The same is not true of countries that undertook money-based stabilization programs. 


\section{Appendix 1: Proof of Proposition 4.4}

The system of equations (3.4), (3.8) and (3.11) in the text can be written compactly as

$$
\begin{gathered}
B\left(g^{*}, i_{1}^{*}, \mu_{1}\right) \equiv(1+r)\left(b_{0^{-}}+m_{0^{-}}\right)+g^{*}-\tau y\left(\frac{2+r}{1+r}\right)-\left(i_{1}^{*}\right)^{1-\epsilon}\left[1+(1+r)^{-1} \sigma h\left(i_{1}^{*}, \mu_{1}\right)\right]=0 \\
F\left(g^{*}, i_{1}^{*}, \mu_{1}\right) \equiv u^{\prime}\left(g^{*}\right)-\left(\frac{1-\alpha}{\alpha}\right)\left(\frac{\epsilon}{1-\epsilon}\right)\left[\frac{1+\beta \sigma h\left(i_{1}^{*}, \mu_{1}\right)}{1+(1+r)^{-1} \sigma h\left(i_{1}^{*}, \mu_{1}\right)}\right]=0
\end{gathered}
$$

where

$$
h\left(i_{1}^{*}, \mu_{1}\right) \equiv\left[\frac{1+r-i_{1}^{*}}{1-\mu_{1}}\right]^{\frac{\epsilon-1}{\epsilon}}>0
$$

and where $\sigma>0$ is the elasticity of $\left(i_{2}^{*}\right)^{1-\epsilon}$ with respect to $\left(i_{1}^{*}\right)^{1-\epsilon}$, held constant around the initial equilibrium.

Totally differentiating (7.1) and (7.2) we see that

$$
\frac{d g^{*}}{d \mu_{1}}=\frac{\left(\frac{B_{\mu_{1}}}{B_{i_{1}^{*}}}\right)-\left(\frac{F_{\mu_{1}}}{F_{i_{1}^{*}}}\right)}{\left(\frac{F_{g^{*}}}{F_{i_{1}^{*}}^{*}}\right)-\left(\frac{B_{g^{*}}}{B_{i_{1}^{*}}^{*}}\right)}
$$

where the subscripts represent partial derivatives. Second order conditions of the FA's problem can easily be shown to guarantee that the denominator of the R.H.S. of 7.4 is positive.$^{25}$ The numerator, on the other hand, is equal to

$$
h\left(i_{1}^{*}, \mu_{1}\right)^{\left(\frac{\varsigma}{\epsilon-1}\right)}\left\{\frac{\epsilon\left[1+r+h\left(i_{1}^{*}, \mu_{1}\right)\right]\left[1+r-i_{1}^{*}\right]}{\epsilon\left[1+r+h\left(i_{1}^{*}, \mu_{1}\right)\right]\left[1+r-i_{1}^{*}\right]+h\left(i_{1}^{*}, \mu_{1}\right)}\right\}>0
$$

We conclude that $\frac{d g^{*}}{d \mu_{1}}>0$.

${ }^{25}$ This denominator, of course, is equal to the determinant of the matrix of partial derivatives of the $2 \times 2$ system in $i_{1}^{*}$ and $g^{*}$, linearized and evaluated at the initial equilibrium. 


\section{Appendix 2: Review of Country Experiences}

\subsection{Chile 1974-1978 ${ }^{26}$}

In April of 1975 the Chilean military government launched a so-called "shock therapy" plan that explicitly singled out monetary policy as its main tool for reducing inflation. An extremely tight monetary policy was applied that year and in the two years that followed. The exchange rate was unified at the start of the program and devalued repeatedly to compensate for the inflation differential between Chile and its trading partners.

A drastic fiscal adjustment accompanied these policies. The socialist government in power until 1973 had given rise to the largest deficits in Chile's history. In 1974, despite some initial adjustment, the nominal fiscal deficit stood at 6.5 percent of GDP. A tax reform and spending cuts implemented in 1975 produced a small nominal surplus in 1975 and a larger surplus (1.2 percent of GDP) the following year. The primary balance showed a comparable improvement. Chile enjoyed stable fiscal surpluses for the remainder of the decade.

\subsection{Argentina $1978-80^{27}$}

Argentina instituted a preannounced crawling peg in December 1978 as part of a broader package of stabilization and liberalization. This system, with some minor variations, remained in place until July 1982. The preannouncement of the nominal exchange rate for rather lengthy periods (for instance, the December 1978 announcement held until August 1979) was meant to signal a credible and swift convergence to world inflation rates.

Argentina's fiscal performance made this impossible. The large fiscal deficit of 6.5 percent of GDP at the time the program was launched remained the same in the next calendar year (1979) and increased to 7.5 percent of GDP in 1980. Similarly, the primary deficit increased (as a share of GDP) in every year the crawling peg was in place.

\footnotetext{
${ }^{26}$ See Diaz-Alejandro (1981), Corbo (1985), Edwards and Edwards (1987), Ramos (1987), Corbo and de Melo (1987).

${ }^{27}$ See Diaz-Alejandro (1981), Calvo (1986b), Corbo and de Melo (1987), Kiguel and Liviatan (1988), Ramos (1987), Vegh (1992).
} 


\subsection{Chile 1978-81 28}

Having failed decisively to lower inflation through the money-based stabilization package of the mid-1970s, Chile introduced a preannounced crawling peg in February 1978 and fully fixed the exchange rate against the US dollar in June 1979. This parity was to survive until June 1982. As in Argentina, the government publicly stressed the role of the fixed parity as a source of discipline and a signal of quick inflation convergence.

Unlike the other South-American fixers of that period (especially Argentina), Chile had adjusted its fiscal imbalance before it adopted a predetermined exchange rate system. In 1978 Chile had a nominal surplus of 1.4 percent of GDP, and a primary surplus of 3.0 percent of GDP. The fiscal stance became even tighter in the two years that followed, reaching a nominal surplus of 5.4 percent of GDP in 1980. Fiscal accounts deteriorated somewhat in the next five years as a result of external shocks and a very large domestic recession, but recovered in the mid1980s. Chile was practically unique in Latin America in that it retained cautious fiscal management throughout the 1980s and early 1990 s.

\subsection{Uruguay $1978-82^{29}$}

The preannouncement of a crawling exchange rate began in Uruguay in October 1978, and was to remain in place until the end of 1982. As in Argentina and Chile, the exchange rate policy was part of a broader stabilization and liberalization effort.

The initial 1978 fiscal situation involved a small nominal deficit of 1.3 percent of GDP, one percent of which corresponded to net interest payments, yielding a primary deficit of only 0.3 percent of GDP. There was a small yet non-negligible improvement in the fiscal stance, which led to a nominal surplus of 1.1 percent of GDP in 1980. This improvement was due both to an increase in current revenues (especially revenues of public sector enterprises, whose prices were allowed to catch up with previous inflation) and to a reduction in current expenditures (from 30.6 to 27.1 percent of GDP between 1978 and 1979). But the fiscal bonanza did not last. After a small deterioration in 1981, fiscal accounts swung to a nominal

\footnotetext{
${ }^{28}$ See Diaz-Alejandro (1981), Edwards and Edwards (1987), Corbo and de Melo (1987), Ramos (1987), Kiguel and Liviatan (1988), Vegh (1992).

${ }^{29}$ See Diaz-Alejandro (1981), Corbo and de Melo (1987), Ramos (1987), Kiguel and Liviatan (1988), Vegh (1992).
} 
deficit of 11.1 percent of GDP in 1982 (10.8 percent primary deficit). Some of the problem was due to a loss of tax revenue associated with the recession, but the main cause of the deficit was current expenditures, which rose from 33.2 percent of GDP in 1981 to 38.3 percent in 1982. Politically sensitive items such as wages, salaries and social security transfers led this trend. ${ }^{30}$

\subsection{Bolivia 1984-87 ${ }^{31}$}

The Bolivian annualized inflation rate reached 123,730 percent (Vegh, 1992) in the first quarter of 1985, and a drastic stabilization plan was put into place in April of that year. Unlike most other efforts at ending hyper-inflation, the Bolivian plan did not involve a fixed exchange rate. The system is best described as a dirty float: the Central Bank held daily auctions at which agents could freely buy and sell foreign exchange, but it never made public targets for either the price or the quantity it aimed for at these auctions. ${ }^{32}$ After a large initial devaluation, the exchange rate became quite stable; this has led some analysts (most notably Sachs, 1987), to argue that the exchange rate acted as a de facto anchor. For our purposes, however, the absence of a preannounced exchange rate target means that the alleged disciplinary factors operating under a fixed parity need not have been present.

The fiscal turnaround in Bolivia was quite dramatic but also short-lived. The nominal deficit went from 25.7 percent of GDP in 1984 to 2.7 percent in 1986. The change in the primary balance was even more drastic: it swung from a deficit of 23.2 percent of GDP in 1984 to a surplus of 2.2 percent in 1986 . Fiscal accounts deteriorated again in 1987 as a result of a sharp terms-of-trade shock. A stable and medium-sized nominal budget deficit (around 4 percent of GDP), coupled with low inflation, has been the norm since $1987 .^{33}$

\footnotetext{
${ }^{30}$ See ECLAC (1982).

${ }^{31}$ See Sachs (1987), Kiguel and Liviatan (1988), Morales (1991), Vegh (1992).

${ }^{32}$ For details, see Dominguez (1991).

${ }^{33}$ See ECLAC (1993).
} 


\subsection{Argentina $1984-87^{34}$}

Argentina was one of four Latin American countries (Peru, Brazil and Mexico were the others) that adopted so-called "heterodox" stabilization packages in 1985-86. These programs combined a fixed exchange rate and other standard measures with wage and price controls. In June 1985 the government announced the Austral Plan, a key feature of which was the fixing of the exchange rate. The strict parity was maintained until April 1986, when the government adopted a policy of periodic mini-devaluations.

In 1984 the nominal fiscal deficit had stood at almost 12 percent of GDP; it fell to 6 percent in 1985 and to 4.7 percent in 1986, as the government readjusted public sector prices, and as tax collection increased because of strong output growth. But in the absence of lasting tax and spending reforms, the fiscal re-balancing was short-lived. By 1987, the nominal deficit had grown to 7.2 percent of GDP, and it was to increase even more thereafter. There is consensus (see Dornbusch and Simonsen (1987), Heymann (1991)) that lack of serious fiscal adjustment caused the eventual demise of the Argentinian stabilization plan.

\subsection{Peru 1984-87}

The "heterodox" stabilization program in Peru began in July 1985. At that time the exchange rate was fixed vis a vis the US dollar. In an attempt to influence inflationary expectations, the government stressed that several key prices (under official control) and the exchange rate would be fixed for a long time. The parity held until the end of 1986 .

There was a short-lived fiscal contraction inPeru in 1985. The nominal deficit shrank from 6.6 percent of GDP in 1984 to 2.7 percent in 1985. After that the government embarked on a sharp fiscal expansion. The nominal deficit once again reached 6.6 percent of GDP in 1987, and remained at comparable levels for the rest of the decade. By 1989, Peru was in the throes of hyperinflation.

\footnotetext{
${ }^{34}$ See Dornbusch and Simonsen (1987), Heymann (1991), Kiguel and Liviatan (1992a and b), Vegh (1992).

${ }^{35}$ See Dornbusch and Simonsen (1987), Sachs and Paredes (1991) and Kiguel and Liviatan (1992a and $b)$.
} 


\subsection{Brazil 1985-88}

Brazil's Cruzado Plan froze the exchange rate along with public sector prices and most private wages and prices in February 1986. The government made a deliberate and much discussed attempt to guide inflationary expectations by means of the exchange rate anchor. It imposed a second freeze under the socalled Bresser Plan in June 1987.

This plan was adopted in a context of mild fiscal disequilibrium, and the government made no serious effort to balance public finances. The operational deficit decreased from 3.7 percent of GDP in 1986 to 2.6 percent in 1986 (largely because a domestic boom increased revenues) and grew back to 4.3 percent in 1987. The primary deficit followed a similar trajectory. Cardoso (1991) writes: "There is no controversy about the reasons why the Cruzado Plan failed. The most prominent reason was the overheating of the economy through loose fiscal and monetary policies..."

\subsection{Mexico $1986-89^{37}$}

Mexico launched the Solidarity Pact in December 1987, which froze prices and wages. Unlike other freezes, Mexico's was achieved through a "pact" between government, business and labor unions. The government also froze the exchange rate, and it remained fixed (except for a minor adjustment in February 1988) until January 1989. The government then instituted a preannounced rate of crawl. With some variations in the speed of crawl (and with the eventual creation of a band around the target rate) the system remained in place until December 1994.

Unlike the other countries that adopted "heterodox" policies, Mexico had stabilized its fiscal situation before it fixed the exchange rate. After a period of fiscal populism in the late 1970 s and early 1980s, Mexico undertook a gradual fiscal consolidation, which narrowed the operational deficit to 2.5 percent of GDP (and the primary balance to a small surplus) in 1986, in spite of a massive terms-of-trade shock that year. By 1987, Mexico had an operational surplus of 1.8 percent of GDP. Matters were complicated in 1988, as very high real interest rates at home caused an operational deficit; nonetheless, the fiscal effort continued, as evidenced by a growing primary surplus that reached 4.4 percent of GDP that year. The

\footnotetext{
${ }^{36}$ See Dornbusch and Simonsen (1987), Cardoso (1991) and Kiguel and Liviatan (1992a and b).

${ }^{37}$ See Ortiz (1991), Kiguel and Liviatan (1992b), Aspe (1993).
} 
situation was stabilized in 1989 and the years that followed. Mexico has continued to have sound public finances, though in 1994 the trend was reversed somewhat as a result of pressures arising from a contested presidential election and the need to subsidize a troubled banking sector. ${ }^{38}$

\subsection{Brazil 1990-92 ${ }^{39}$}

With the advent of a new administration, Brazil launched a new stabilization plan in March 1990. By then the country was in the throes of hyperinflation: prices increased by 1287 percent in 1989 and the speed of price increases was accelerating. Tight money was the main anchor of the program: the exchange rate had a passive role and simply accommodated inflation.

The plan broke with earlier Brazilian tradition by delivering on promises to close the fiscal deficit. The operational deficit swung from almost 7 percent of GDP in 1989 to slightly over 1 percent in 1990; that year the primary balance was almost zero. The following year witnessed a growing primary surplus and a small operational deficit. Despite some backsliding in 1992, Brazil has continued to enjoy primary surpluses and small operational deficits through the present (1994).

\subsection{Peru 1989-1992}

Inflation in Peru was 3400 percent in 1989 and 7482 percent in 1990. In August of 1990 a newly-elected government put a stringent stabilization plan into place. The plan included explicit targets for domestic credit to the government, and used money as the nominal anchor. The exchange rate was allowed to float freely, though it stabilized quickly after a large initial depreciation.

The resulting fiscal adjustment was large, shrinking the nominal deficit from 7.1 percent of GDP in 1989 to 4.5 percent in 1990 to 1.6 percent in 1991; by that year there was a primary surplus of 1.7 percent of GDP. The initial adjustment was accomplished through higher taxes, enhanced collection and a drastic increase in public sector prices; spending was already very low and reducing it further

\footnotetext{
${ }^{38}$ See Sachs, Tornell and Velasco (1995).

${ }^{39}$ See Kiguel and Liviatan (1992b), Barbosa and Giambiagi (1993), Calvo and Vegh (1994) and Sachs and Zini (1994).

${ }^{40}$ See Kiguel and Liviatan (1992b) and Calvo and Vegh (1994).
} 
did not seem realistic. In the years since, structural reforms, including largescale privatization, have continued to shore up public finances. As a result, the government achieved small deficits (1.8 and 1.4 percent of GDP) in 1992 and 1993.

\subsection{Dominican Republic 1989-92 ${ }^{41}$}

The Dominican Republic, facing rising inflation and a growing current account deficit, launched a stabilization program in August 1990. Money was the program's nominal anchor. The government devalued the exchange rate several times in the second half of 1990, established a dual exchange rate in January 1991 and, finally, adopted unification and a flexible rate system in July 1991.

A substantial fiscal disequilibrium was at the root of the Dominican Republic's earlier problems, with the nominal fiscal deficit at a level of 6.9 percent of GDP in 1988 and 5.9 percent in 1989 . The stabilization promised and delivered a drastic fiscal turnaround. By 1991 the nominal deficit had been eliminated and there was a primary surplus of 4.2 percent of GDP. This tendency was strengthened in 1992.

\subsection{Argentina 1989-1992 ${ }^{42}$}

Inflation in Argentina reached 3080 percent in 1989. During that year and the next two years, the government implemented several short-lived stabilization plans, which had the effect of lowering the inflation rate to less extreme (but still very high) levels. In April 1991 the Convertibility Plan was introduced, which had as its main component not just the fixing of the exchange rate, but also the creation of a currency board and the approval of constitutional amendments setting tight and explicit limits on the ability of the Central Bank to finance fiscal deficits.

An important fiscal adjustment took place during the 1989-1990 period, in which the nominal deficit was halved as a result of spending cuts, tighter tax enforcement and the rescheduling and redenomination of the domestic debt. By 1990, the year before the Convertibility Plan was implemented, the primary deficit was all but eliminated. In 1991 there was a primary surplus equal to 1 percent of GDP. The process of fiscal consolidation has continued since then, with the attainment of nominal balance and an ongoing primary surplus in 1993.

\footnotetext{
${ }^{41}$ See Medeiros (1993) and Calvo and Vegh (1994).

${ }^{42}$ See Kiguel and Liviatan (1992b), Calvo and Vegh (1994).
} 


\section{References}

[1] Aghevli, B. M. Khan and P. Montiel "Exchange Rate Policies in Developing Countries: Some Analytical Issues" IMF Occasional Paper No. 78, March 1991.

[2] Aspe, P. Economic Transformation: The Mexican Way Cambridge, The MIT Press, 1993.

[3] Barbosa, F. and F. Giambiagi "O Ajuste Fiscal de 1990-93: Uma Análise Retrospectiva" mimeo, 1994.

[4] Barro, R. and D. Gordon "A Positive Theory of Monetary Policy in a Natural Rate Model" Joumal of Political Economy, 1983.

[5] Bruno, M., G. di Tella, R. Dornbusch and S. Fischer (eds.) Inflation Stabilization: The Experience of Israel, Argentina, Brazil, Bolivia and Mexico. Cambridge: MIT Press, 1988.

[6] Bruno, M., S. Fischer, E. Helpman, N. Liviatan and L. Meridor (eds.) Lessons of Economic Stabilization and its Aftermath Cambridge: MIT Press, 1991.

[7] Calvo, G. "On the Time Consistency of Optimal Policy in a Monetary Economy" Econometrica, 1978.

[8] _-__ "Temporary Stabilization: The Case of Predetermined Exchange Rates" Journal of Political Economy, 1986a.

[9] ______ "Fractured Liberalism: Argentina under Martínez de Hoz" Economic Development and Cultural Change, $1986 \mathrm{~b}$.

[10] ____ "Balance of Payments Crises in a Cash in Advance Economy" Journal of Money, Credit and Banking, 1987.

[11] ____ "Temporary Stabilization Policy: The Case of Flexible Prices and Exchange Rates" Journal of Economic Dynamics and Control, 1991.

[12] _____ and C. Vegh "Inflation Stabilization and Nominal Anchors" Contemporary Economic Policy, Vol. XII, April 1994. 
[13] Cardoso, E. "From Inertia to Megainflation: Brazil in the 1980s" in Bruno et al (1991).

[14] Corbo, V. "Reforms and Macroeconomic Adjustment in Chile during 197478" World Development, Vol. 13, 1985.

[15] ___ and J. de Melo "Lessons from the Southern Cone Policy Reforms" World Bank Economic Review, 1987.

[16] Díaz-Alejandro, Carlos "Southern Cone Stabilization Plans" in W. Cline and S. Weintraub (eds.) Economic Stabilization in Developing Countries Washington: The Brookings Institution, 1981.

[17] Domínguez, K. "Do Exchange Rate Auctions Work? An Examination of the Bolivian Experience" NBER Working Paper No. 3683, April 1991.

[18] Dornbusch, R. and M.H. Simonsen "Inflation Stabilization with Incomes Policy Support" Group of Thirty, New York, 1987.

[19] ____ and S. Edwards (eds.) The Macroeconomics of Populism in Latin America Chicago: The University of Chicago Press, 1991.

[20] Drazen, A. "Tight Money and Inflation: Further Results" Joumal of Monetary Economics, Vol. 15, 1984.

[21] ECLAC Las Finanzas Públicas de América Latina en la Década de 1980 Santiago: Naciones Unidas, 1992.

[22] ___ Estudio Económico de América Latina y el Caribe, 1993 Santiago: Naciones Unidas, 1993.

[23] Edwards, S. and A. Cox-Edwards Monetarism and Liberalization: The Chilean Experiment Cambridge: Ballinger Publishing Company, 1987.

[24] Frenkel, J. M. Goldstein and P. Masson "Characteristics of a Successful Exchange Rate System" IMF Occasional Paper No. 82, July 1991.

[25] Hausmann, R. Shocks Externos y Ajuste Macroeconómico Caracas: Banco Central de Venezuela, 1990. 
[26] Helpman, E. "An Exploration into the Theory of Exchange Rate Regimes" Journal of Political Economy Vol. 89, 1981.

[27] __ and A. Razin "Toward a Consistent Comparison of Alternative Exchange Rate Regimes" Canadian Journal of Economics, 1979.

[28] Heymann, D. "From Sharp Disinflation to Hyperinflation, Twice: The Argentine Experience, 1985-89" in Bruno et al (1991).

[29] Johnson, H. "The Case for Flexible Exchange Rates, 1969" Federal Reserve Bank of St. Louis Review, Vol. 51, June 1969.

[30] Kiguel, M. and N. Liviatan "Inflationary Rigidities and Orthodox Stabilization Policies: Lessons from Latin America" The World Bank Economic Review, Vol. 2, No. 3, 1988.

[31] _W_______ "When Do Heterodox Stabilization Programs Work?" The World Bank Economic Review, Vol. 7, No. 1, 1992a.

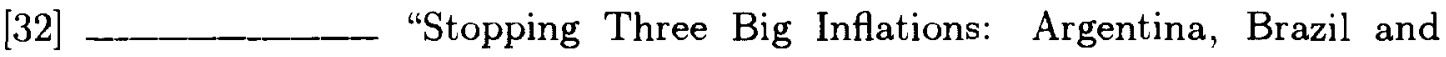
Peru" Country Economics Department, WPS 999, The World Bank, October 1992b.

[33] Klein, M. and N. Marion "Explaining the Duration of Exchange Rate Pegs" NBER Working Paper No.4651, February 1994.

[34] Krugman, P. Exchange Rate Instability Cambridge: The MIT Press, 1989.

[35] Liviatan, N. "Tight Money and Inflation" Journal of Monetary Economics Vol. 13, 1984.

[36] Medeiros, C. "The Dominican Republic's Stabilization Plan of 1990-92: Was it a Monetary Stabilization Program?" mimeo, IMF, 1993.

[37] Morales, J.A. "The Transition from Stabilization to Sustained Growth in Bolivia" in Bruno et al (1988).

[38] Obstfeld, M. "Floating Exchange Rates: Experience and Prospects" Brookings Papers on Economic Activity, 1985. 
[39] Ortiz, G. "Mexico Beyond the Debt Crisis: Toward Sustainable Growth with Price Stability" in Bruno et al (1991).

[40] Ramos, J. Neoconservative Economics in the Southern Cone of Latin America 1973-1983 Baltimore: The Johns Hopkins University Press, 1987.

[41] Sachs, J. "The Bolivian Hyperinflation and Stabilization" NBER Working Paper No. 2073, 1987.

[42] __ and A. Zini "Brazilian inflation and the Plano Real" mimeo, Harvard University, 1994.

[43] ____, A. Tornell and A. Velasco, "The Collapse of the Mexican Peso: What Have We Learned?" mimeo, Harvard University, 1995.

[44] Sargent, T. and N. Wallace "Some Unpleasant Monetarist Arithmetic" Federal Reserve Bank of Minneapolis Quarterly Review, 1981.

[45] Vegh, C. "Stopping High Inflation: An Analytical Overview" IMF Staff Papers, September 1992. 
Table 1: Fiscal Adjustment

\begin{tabular}{|l|c|c|c|c|}
\hline Country & $(\mathrm{t}-1)$ & $\mathrm{t}$ & $(\mathrm{t}+1)$ & $(\mathrm{t}+2)$ \\
\hline Chile (75) & & & & \\
Nominal Balance & -6.5 & 0.2 & 1.2 & 0.0 \\
Primary Balance & -5.6 & 1.8 & 2.8 & 1.0 \\
\hline Argentina (78) & & & & \\
Nominal Balance & -6.5 & -6.5 & -7.5 & -13.2 \\
Primary Balance & -3.5 & -3.4 & -4.0 & -5.8 \\
\hline Chile (78) & & & & \\
Nominal Balance & 0.0 & 1.4 & 4.6 & 5.4 \\
Primary Balance & 1.0 & 3.0 & 5.8 & 6.2 \\
\hline Uruguay (78) & & & & \\
Nominal Balance & -1.3 & 0.3 & 1.1 & -1.8 \\
Primary Balance & -0.3 & 1.0 & 1.6 & -1.4 \\
\hline Argentina (85) & & & & \\
Nominal Balance & -11.9 & -6.0 & -4.7 & -7.2 \\
Primary Balance & -7.0 & -0.6 & -0.9 & -3.6 \\
\hline Bolivia (85) & & & & \\
Nominal Balance & -25.7 & -10.3 & -2.7 & -7.8 \\
Primary Balance & -23.2 & -4.4 & 2.2 & -3.7 \\
\hline Peru (85) & & & & \\
Nominal Balance & -6.6 & -2.7 & -5.1 & -6.6 \\
Primary Balance & -0.7 & 3.1 & -1.8 & -4.0 \\
\hline Brazil (86) & & & & \\
Oper. Balance & -3.7 & -2.6 & -4.3 & -5.0 \\
Primary Balance & 2.6 & 1.8 & 1.7 & 1.3 \\
\hline Mexico (87) & & & & \\
Oper. Balance & -2.5 & 1.8 & -3.5 & -2.0 \\
Primary Balance & 0.5 & 3.8 & 4.4 & 7.2 \\
\hline Brazil (90) & & & & \\
Oper. Balance & -6.9 & -1.2 & -1.4 & -2.1 \\
Primary Balance & -1.1 & -0.3 & 1.4 & 1.3 \\
\hline Dom. Republic (90) & & & & \\
Nominal Balance & -5.9 & -5.0 & 0.1 & 1.6 \\
Primary Balance & -1.9 & -1.0 & 4.2 & 4.6 \\
\hline Peru (90) & & & & \\
Nominal Balance & -7.1 & -4.5 & -1.6 & -1.8 \\
Primary Balance & -3.6 & 0.1 & 1.7 & 0.9 \\
\hline Argentina (91) & 36 & & & \\
Nominal Balance & -3.8 & -1.6 & -0.1 & -0.1 \\
Primary Balance & -0.5 & 1.0 & 1.4 & 1.0 \\
\hline
\end{tabular}


Chile (75) Source: Ministerio de Hacienda (1980) Note: All figures as a percentage of GDP. Figures are for central government.

Argentina (78) Source: ECLAC (1992) Note: All figures as a percentage of GDP. Figures are for the non-financial public sector.

Chile (78) Source: ECLAC (1992) Note: All figures as a percentage of GDP. Figures are for the non-financial public sector. Implicit interest payments correspond to the general government only.

Uruguay (78) Source: ECLAC (1992) Note: All figures as a percentage of GDP. Figures are for the non-financial public sector.

Argentina (85) Source: ECLAC (1992) Note: All figures as a percentage of GDP. Figures are for the non-financial public sector.

Bolivia (85) Source: ECLAC (1992) Note: All figures as percentage of GDP. Figures for the consolidated public sector (includes state enterprises). Figures for nominal balance include interest payments capitalized because of moratorium.

Peru (85) Source: ECLAC (1992) Note: All figures as a percentage of GDP. Figures are for the non-financial public sector.

Brazil (86) Source: ECLAC (1992) Note: All figures as a percentage of GDP. Figures are for the consolidated public sector. The operational balance excludes the inflationary component of interest payments.

Mexico (87) Source: ECLAC (1992) Note: All figures as a percentage of GDP. Figures are for the consolidated public sector. Monetary correction on the operational balance estimated by the authors on the basis of Aspe(1993).

Brazil (90) Source: ECLAC (1993) Note: All figures as percentage of GDP. Figures for the consolidated public sector. Both operational and primary balance exclude the inflationary component of interest payments. Estimates based on Barbosa and Giabiagi(1994).

Dom. Rep. (90) Source: Medeiros(1993) Note: All figures as a percentage of GDP. Figures for the consolidated public sector.

Peru (90) Source: ECLAC (1992) Note: All figures as a percentage of GDP. Figures are for the non-financial public sector.

Argentina (91) Source: ECLAC (1993) Note: All figures as a percentage of GDP. Figures are for the non-financial public sector. Implicit interest expenses (primary balance), estimated on the basis of data from the Ministry of the Economy and the Central Bank of Argentina. 
Table 2: Latin American Stabilizations

\begin{tabular}{|c|c|c|c|}
\hline Type & No Fiscal Adjustment & $\begin{array}{c}\text { Fiscal Adjustment } \\
\text { Before Stabilization }\end{array}$ & $\begin{array}{c}\text { Fiscal Adjustment } \\
\text { During Stabilization }\end{array}$ \\
\hline $\begin{array}{c}\text { Money-Based } \\
\text { Stabilization }\end{array}$ & Bolivia 1985 & & $\begin{array}{c}\text { Chile 1975 } \\
\text { Brazil 1990 } \\
\text { Peru 1990 } \\
\text { Dom. Republic 1990 }\end{array}$ \\
& & & \\
\hline $\begin{array}{c}\text { Exchange Rate-Based } \\
\text { Stabilization }\end{array}$ & $\begin{array}{c}\text { Argentina 1978 } \\
\text { Argentina 1985 } \\
\text { Peru 1985 } \\
\text { Brazil 1986 }\end{array}$ & $\begin{array}{c}\text { Mexico 1987 } \\
\text { Uruguay 1978 }\end{array}$ & Argentina 1991 \\
& & & \\
\hline
\end{tabular}

